\author{
B. Naukenova ${ }^{1}$, A. Pyagay ${ }^{2, *}$ \\ ${ }^{1}$ «Turan-Astana» University, Dukenuly str., 29, Nur-Sultan \\ ${ }^{2}$ Saken Seifullin Kazakh Agrotechnical University \\ 'bnaukenova14@mail.ru,_pyagay72@mail.ru \\ ${ }^{1}$ https://orcid.org/0000-0002-9001-753X, ${ }^{2}$ https://orcid.org/0000-0002-1590-872X \\ ${ }^{2}$ Scopus Author ID: 56127534300 \\ ${ }^{2}$ Researcher ID: $A A C-4047-2020$
}

\title{
Assessment of the resource potential of agricultural production and determination of the level of efficiency of its use (on the example of regions of the Republic of Kazakhstan)
}

\begin{abstract}
Object: the resource potential assessment (natural, labor, material and technical, etc.) of the Republic of Kazakhstan agricultural sector and the determination of constraining factors for its development.

Methods: 1. Economic assessment of land and material resources, the amount of which is presented as an indicator of the resource supply farms.

2. Economic and statistical methods reflecting the link between productive resources and production results.

3. Index methods for assessing resource potential, taking the characteristics of its constituent elements.

Findings: 1. Assessment of the agricultural land productive capacity was carried out through the indicator of the agricultural production annual volume in all categories of farms in accordance with its cadastral value per 1 ha, as well as crop production per 1 ha of arable land using the index method.

2. Assessment's the agricultural production resource potential includes the consistent assessment: first, resources availability, then the agricultural production economic efficiency and, finally, the resource use efficiency in the agricultural production subjects.

Conclusions: It was defined the resulting indicators complex, which reflecting the availability's level of agricultural production resources in the regions, including 10 indicators.
\end{abstract}

Keywords: agricultural production, resource potential, agricultural sector, economic efficiency, resource use efficiency, integrated assessment, agro-industrial complex (AIC).

\section{Introduction}

At the present stage in the national agro-industrial complex there are a number's unresolved problems associated with a reduction of the sector production and technical potential, a difficult financial situation, the agricultural market and competitive environment insufficient development, and low investment attractiveness.

The resources' shortage especially acute the importance of increasing their use efficiency, which acts as the main direction of sustainable the agricultural sector development. Assessing the resource potential value and its implementation degree, its structural changes and its elements interaction characteristics, the prospects for their development plays an important role not only in the resource potential reproduction, but also in increasing all agricultural production efficiency (Davydkina, 2015).

The relevance of the research problem, the need to develop methodological approaches to assessing the agricultural production resource potential, increasing its use efficiency and labor productivity in AIC, also assessing the resource potential for the Republic of Kazakhstan agricultural sector development determined the choice of theme, research object and subject, and led to the formulation the research purpose.

The research purpose is to develop methodological approaches to assessing the agricultural production resource potential and assessing the resource potential (natural, labor, material and technical, etc.) of Republic of Kazakhstan agricultural sector development.

\section{Literature Review}

Substantial contribution to the rational use of natural resources research made foreign economists as: J. Borts, H. Siebert, D. Keynes, M.L. Lurie, C. Marx, A. Marshall, V. Nordhouse, P. Samuelson, A. Smith, N. Robinson, R. Sullow, E. Scott and others. Theoretical and practical wide range issues on determining and

\footnotetext{
* Corresponding author.

E-mail address: pyagay72@mail.ru
} 
increasing the resource potential use efficiency is presented in the next scientists' works: P.M. Pershukevich, A.E. Yuzefovich, T. Shabanova, N.N. Ibrishev and others.

P.M. Pershukevich treats the agro-industrial complex (AIC) resource potential of the region, territory and republic as «a combination of natural and climatic, industrial, scientific and technical conditions and the matching infrastructure which able to satisfy the social needs for the agro-industrial complex products» (Pershukevich, 2001).

A.E. Yuzefovich considers that «the agrarian resource potential of farms and regions is determined by the availability, quality and balance of natural, biological, material and labor resources, in which interaction process is realized their integral ability to produce its adequate products amounts and types» (Yuzefovich, 1987). Moreover, when changing the resource potential structure, a regular process is an increase the share of its most significant and high-productive elements - as a result of applying intensive farming methods.

Thus, resource and production potentials are recognized and accepted in economic science as an economic category, which means the possibility's and necessity's quantitative estimates their values with further use in determining the agricultural production economic efficiency.

So, with regard to the agricultural sector, we determine the resource potential as a combination's a certain amount and quality resources necessary for reproduction, due to both the specifics and features' the current state of agriculture in Kazakhstan, taking into account the regional aspect, as well as their ability to maximize the economic effect at the optimal combination.

\section{Methods}

Currently, there are many different methodological recommendations for assessing the resource potential, which are based on four basic methodological approaches that solve the impact assessing problem of qualitatively various resources on production and economic activities effective performance indicators:

1. Land and material resources economic assessment, which amount is presented as the resource supply indicator of farms.

After studying the publications (Bronstein,1972; Krastin, Godman, 1984; Kalninsha, 1998; Davis, Gephart, Emery, Leach, Galloway, 2016; Minviel, \& Latruffe, 2017) we came to the conclusion that economic and statistical models based on the calculated effective indicator give only indirectly, and due to its fluctuations, a very relative representation about the development degree and agricultural resource potential use.

2. Economic and statistical, reflecting the link between productive resources and production results. Obtained using these models calculated level of the effective indicator is considered as a generalized assessment of the farms resource abilities and is used to compare with the achieved production volume.

Taking into account the studied methodological provisions (Mogaji, Lim, \& Abdullah, 2015; Walters, Archer, Sassenrath, Hendrickson, Hanson, Halloran, \& Alarcon, 2016; Baráth, \& Fertő, 2017), it should be noted, that economic and statistical models based on the calculated effective indicator give only indirectly, and due to its fluctuations, a very relative representation about the development degree and agricultural resource potential use. Besides, the regression model can be only used in research of similar objects, for example, farms or areas with close specialization. Otherwise, the effective indicators calculated values for individual different-quality groups will not be comparable.

3. Recommended index methods for assessing resource potential, taking into account the characteristics of its constituent elements (Romanova, Bryanceva, Pozdnyakova, 2013).

4. As the most acceptable alternative methodology is proposed monetary assessment of agricultural resources and, based on it, to determine their productive capacity. To solve this problem, in the economic literature are mainly used two methodological approaches: productive resources transfer into the cost (named) forms, which can be summed up, and the interchangeability principle of certain types' resources (Alhazov, 2011).

Based on the available methodological approach's generalization assessment of the agricultural production resource potential, we conduct its economic efficiency on the basis a complex analysis and forecasting. This approach includes consistent assessment where first is considered resource potential, then the agricultural production economic efficiency and, finally, the resource use efficiency in the agricultural production subjects. On the basis of an indicators complex can be judged the resource reserves level, their use appropriateness in various agricultural production fields. To do this, for all types' resources (natural: land, water; ma- 
terial and technical; labor; infrastructure; financial) based on analysis of the totality indicators are selected the resulting indicators.

To assess the agricultural production economic efficiency is necessary to determine the production level of gross output and profits. The complex resulting indicators reflecting the level of agricultural production efficiency in the regions includes the following indicators (De Olde, Oudshoorn, Sørensen, Bokkers, \& De Boer, 2016):

- Produced of agricultural production gross output per 1 ha of agricultural land, million tenge/ha (APGO);

- Profit from the agricultural products sale per 1 ha of agricultural land, million tenge/ha (PAP);

- Indicators indexes of agricultural production efficiency in regions are determined similarly to the indicators index of resource supply.

To assess the resource potential use efficiency is calculated the weighted average index of the total resource potential and the average efficiency index manufacturing (APEIM) (Gutzler, Helming, Balla, Dannowski, Deumlich, Glemnitz, \& Sieber, 2015).

$$
\text { APEIM }=\text { indexes }(\text { APGO }+ \text { PAP }) / 2 \times 100 .
$$

Based on these indicators is determined level of resource potential utilization efficiency (LRPUE) (RPUEL) of the region and the republic as a whole.

To assess the resource potential use efficiency is calculated the weighted average index of the total resource potential (WAITRP) (Yang, \& Zhang, 2018):

$$
\mathrm{WAITRP}=[\text { indexes }(\mathrm{AALRW}+\mathrm{ANW}+\mathrm{SBS}+\mathrm{MFI}+\mathrm{TNF}+\mathrm{MNF}+\mathrm{NCHF}+\mathrm{SRSRP}) / 8] \times 100
$$

where: AALRW - the area of agricultural land per 1 rural worker;

ANW - the average number of workers employed in the agricultural sector per 100 ha of farmland;

SBS - Soil bonitet score;

MFI - The mineral fertilizers introduction per 1 ha of farmland;

TNF - The tractors' number per 1000 ha of farmland;

MNF - Trailed and mounted machines number per 1 ha of farmland;

NCHF - Number of combine harvester per 1 ha of farmland;

SRSRP - The share of rural settlements with roads to the district center with a paved.

$$
\text { LRPUE }=\text { APEIM } / \text { WAITRP. }
$$

\section{Results}

The complex resulting indicators reflecting the level of agricultural production supply in the regions with resources includes the following indicators:

- The area of agricultural land per 1 rural worker, \% (AALRW) (table 1);

- The average number of workers employed in the agricultural sector per 100 ha of farmland, pers./ha (ANW) (table 1);

- Soil bonitet score, score (SBS) (table 1);

- The mineral fertilizers introduction per 1 ha of farmland, thousand tenge (MFI) (table 1).

Table 1. Indicators that reflect the level of provision of agricultural production in the regions with resources

\begin{tabular}{|l|c|c|c|c|c|c|c|c|}
\hline \multirow{2}{*}{ Region } & \multicolumn{2}{|c|}{ AALRW* } & \multicolumn{2}{c|}{ ANW* } & \multicolumn{2}{c|}{ SBS* } & \multicolumn{2}{c|}{ MFI* $^{*}$} \\
\cline { 2 - 9 } & ha & $\begin{array}{c}\text { Index } \\
\text { indicator }\end{array}$ & ha & $\begin{array}{c}\text { Index } \\
\text { indicator }\end{array}$ & $\begin{array}{c}\text { Agricultural } \\
\text { lands }\end{array}$ & $\begin{array}{c}\text { Index } \\
\text { indicator }\end{array}$ & $\begin{array}{c}\text { Thousand } \\
\text { tenge }\end{array}$ & $\begin{array}{c}\text { Index } \\
\text { indicator }\end{array}$ \\
\hline \hline \multicolumn{1}{|c|}{1} & 2 & 3 & 4 & 5 & 6 & 7 & 8 & 9 \\
\hline Nothern & 44,3 & 1,6 & 1,4 & 1,0 & 29 & 1,5 & 56153 & 1,4 \\
\hline Akmola & 50,0 & 1,8 & 1,2 & 0,9 & 28 & 1,5 & 70123 & 1,8 \\
\hline Kostanay & 44,6 & 1,6 & 1,6 & 1,1 & 30 & 1,6 & 11220 & 0,3 \\
\hline Pavlodar & 42,7 & 1,6 & 1,4 & 1,0 & 13 & 0,7 & 30353 & 0,8 \\
\hline North Kazakhstan & 38,2 & 1,4 & 1,5 & 1,1 & 44 & 2,3 & 123503 & 3,1 \\
\hline Western & 37,8 & 1,4 & 0,5 & 0,4 & 9 & 0,5 & 2945 & 0,1 \\
\hline Aktobe & 66,6 & 2,4 & 0,4 & 0,3 & 13 & 0,7 & 4026 & 0,1 \\
\hline Atyrau & 15,2 & 0,6 & 0,4 & 0,3 & 4 & 0,2 & 1174 & 0,1 \\
\hline
\end{tabular}




\begin{tabular}{|l|c|c|c|c|c|c|c|c|}
\hline \multicolumn{1}{|c|}{1} & 2 & 3 & 4 & 5 & 6 & 7 & 8 & 9 \\
\hline West Kazakhstan & 37,1 & 1,4 & 1,1 & 0,8 & 14 & 0,7 & 3195 & 0,1 \\
\hline Mangistau & 32,0 & 1,2 & 0,1 & 0,1 & 5 & 0,3 & 1017 & 0,1 \\
\hline Eastern & 38,8 & 1,4 & 1 & 0,7 & 23 & 1,2 & 23720 & 0,6 \\
\hline East Kazakhstan & 38,8 & 1,4 & 1 & 0,7 & 23 & 1,2 & 23720 & 0,6 \\
\hline Central & 101,7 & 3,7 & 0,2 & 0,2 & 12 & 0,6 & 4238 & 0,1 \\
\hline Karaganda & 101,7 & 3,7 & 0,2 & 0,2 & 12 & 0,6 & 4238 & 0,1 \\
\hline South & 10,0 & 0,4 & 3,2 & 2,3 & 12 & 0,6 & 89776 & 2,3 \\
\hline Almaty & 11,5 & 0,4 & 3 & 2,2 & 16 & 0,8 & 51969 & 1,3 \\
\hline Zhambyl & 14,3 & 0,5 & 3,1 & 2,2 & 8 & 0,4 & 91137 & 2,3 \\
\hline Kyzylorda & 10,8 & 0,4 & 1,7 & 1,2 & 10 & 0,5 & 141798 & 3,6 \\
\hline South Kazakhstan & 6,1 & 0,2 & 4,6 & 3,3 & 12 & 0,6 & 143040 & 3,6 \\
\hline
\end{tabular}

- The tractors' number per 1000 ha of farmland, units/ha (TNF) (table 2);

- Trailed and mounted machines number per 1 ha of farmland, units/ha (MNF) (table 2);

- Number of combine harvester per 1 ha of farmland, units/ha (NCHF) (table 2);

- The share of rural settlements with roads to the district center with a paved, \% (SRSRP) (table 2);

Table 2. Indicators that reflect the level of provision of agricultural production in the regions with resources

\begin{tabular}{|l|c|c|c|c|c|c|c|c|}
\hline \multirow{2}{*}{ Region } & \multicolumn{2}{|c|}{ TNF* } & \multicolumn{2}{c|}{ MNF* } & \multicolumn{2}{c|}{ NCHF* } & \multicolumn{2}{c|}{ SRSRP* } \\
\cline { 2 - 9 } & Units/ha & $\begin{array}{c}\text { Index } \\
\text { indicator }\end{array}$ & Units/ha & $\begin{array}{c}\text { Index } \\
\text { indicator }\end{array}$ & Units/ha & $\begin{array}{c}\text { Index } \\
\text { indicator }\end{array}$ & $\%$ & $\begin{array}{c}\text { Index } \\
\text { indicator }\end{array}$ \\
\hline Nothern & 1,9 & 1,3 & 7,85 & 1,9 & 0,9 & 2,3 & 90 & 1,0 \\
\hline Akmola & 1,5 & 1,0 & 4,32 & 1,1 & 0,8 & 2,0 & 92 & 1,0 \\
\hline Kostanay & 2,3 & 1,5 & 10,13 & 2,4 & 1,0 & 2,5 & 90 & 1,0 \\
\hline Pavlodar & 2,1 & 1,4 & 4,27 & 1,0 & 0,4 & 1,0 & 88 & 1,0 \\
\hline North Kazakhstan & 2,0 & 1,3 & 12,66 & 3,0 & 1,1 & 2,8 & 90 & 1,0 \\
\hline Western & 0,9 & 0,6 & 1,97 & 0,5 & 0,1 & 0,3 & 71 & 0,8 \\
\hline Aktobe & 0,7 & 0,5 & 1,45 & 0,3 & 0,2 & 0,5 & 63 & 0,7 \\
\hline Atyrau & 1,2 & 0,8 & 0,34 & 0,1 & 0,1 & 0,3 & 74 & 0,8 \\
\hline West Kazakhstan & 1,7 & 1,1 & 4,75 & 1,1 & 0,2 & 0,5 & 76 & 0,8 \\
\hline Mangistau & 0,1 & 0,1 & 0,01 & 0,1 & 0,1 & 0,3 & 70 & 0,8 \\
\hline Eastern & 1,6 & 1,1 & 3,63 & 0,9 & 0,3 & 0,8 & 92 & 1,0 \\
\hline East Kazakhstan & 1,6 & 1,1 & 3,63 & 0,9 & 0,3 & 0,8 & 92 & 1,0 \\
\hline Central & 0,9 & 0,6 & 1,58 & 0,4 & 0,2 & 0,5 & 95 & 1,1 \\
\hline Karaganda & 0,9 & 0,6 & 1,58 & 0,4 & 0,2 & 0,5 & 95 & 1,1 \\
\hline South & 1,9 & 1,3 & 2,76 & 0,7 & 0,3 & 0,8 & 95 & 1,1 \\
\hline Almaty & 1,4 & 0,9 & 3,22 & 0,8 & 0,2 & 0,5 & 97 & 1,1 \\
\hline Zhambyl & 1,3 & 0,9 & 2,64 & 0,6 & 0,3 & 0,8 & 98 & 1,1 \\
\hline Kyzylorda & 0,9 & 0,6 & 0,88 & 0,2 & 0,5 & 1,3 & 87 & 1,0 \\
\hline South Kazakhstan & 4,4 & 2,9 & 2,86 & 0,7 & 0,4 & 1,0 & 98 & 1,1 \\
\hline Total RK & 1,5 & 1,0 & 4,22 & 1,0 & 0,4 & 1,0 & 90 & 1,0 \\
\hline *according to the Republic of Kazakhstan Ministry of Agriculture data for $2015-2017$ & & & \\
Note- compiled by the authors & \multicolumn{2}{|l|}{} & & & & & \\
\hline
\end{tabular}

These data analysis and calculation was conducted on the example of regions and the republic as a whole. Thus for each indicator is determined the index value as the ratio of the regional indicator to the republican indicator multiplied by 100 .

To assess the agricultural production economic efficiency is necessary to determine the gross output and profit level. The complex resulting indicators reflecting the level of agricultural production efficiency in the regions includes the follow indicators:

- Produced an agricultural production gross output per 100 ha of farmland, thousand tenge/ha (APGO) (table 3);

- Profit from the agricultural products sale per 100 ha of farmland, thousand tenge/ha (PAP) (table 3); 
Assessment of the resource potential...

Table 3. Produced an agricultural production gross output per 100 ha of farmland and profit from the agricultural products sale per 100 ha of farmland, thousand tenge/ha

\begin{tabular}{|l|c|c|c|c|}
\hline \multirow{2}{*}{ Region } & \multicolumn{2}{|c|}{ APGO* $^{*}$} & \multicolumn{2}{c|}{ PAP* } \\
\cline { 2 - 5 } & Thousand tenge & Index indicator & Thousand tenge & Index indicator \\
\hline Nothern & 3815 & 1,0 & 473 & 1,4 \\
\hline Akmola & 3169 & 0,9 & 453 & 1,4 \\
\hline Kostanay & 3107 & 0,8 & 487 & 0,7 \\
\hline Pavlodar & 3300 & 0,9 & 237 & 2,0 \\
\hline North Kazakhstan & 6298 & 1,7 & 669 & 0,2 \\
\hline Western & 1696 & 0,5 & 76 & 0,2 \\
\hline Aktobe & 1855 & 0,5 & 68 & 0,1 \\
\hline Atyrau & 2665 & 0,3 & 49 & 0,4 \\
\hline West Kazakhstan & 2048 & 0,6 & 144 & 0,1 \\
\hline Mangistau & 297 & 0,1 & 10 & 0,8 \\
\hline Eastern & 4007 & 1,1 & 274 & 0,8 \\
\hline East Kazakhstan & 4007 & 1,1 & 274 & 0,3 \\
\hline Central & 1629 & 0,4 & 92 & 1,8 \\
\hline Karaganda & 1629 & 0,4 & 92 & 2,1 \\
\hline South & 7362 & 2,0 & 612 & 1,2 \\
\hline Almaty & 7003 & 1,9 & 690 & 0,4 \\
\hline Zhambyl & 5403 & 1,5 & 413 & 1,7 \\
\hline Kyzylorda & 4123 & 1,1 & 132 & 1,0 \\
\hline South Kazakhstan & 11957 & 3,2 & 911 & 335 \\
\hline Total RK & 3720 & 1,0 & & \\
\hline *according to the Republic of Kazakhstan Ministry of Agriculture data for $2015-2017$ & \\
Note - compiled by the authors & \multicolumn{4}{|l}{} \\
\hline
\end{tabular}

Regions agricultural production efficiency indicators indexes are determined similarly to the resource supply indicators index.

To assess the resource potential use efficiency is calculated the weighted average index of the total resource potential (WAITRP) is determined by formula (2) (table 4):

Table 4. The weighted average index of the total resource potential (WAITRP)

\begin{tabular}{|c|c|c|c|c|c|c|c|c|c|}
\hline \multirow{2}{*}{ Region } & \multicolumn{8}{|c|}{ Indexes } & \multirow{2}{*}{ WAITRP } \\
\hline & AALRW & ANW & SBS & MFI & TNF & MNF & NCHF & SRSRP & \\
\hline Nothern & 1,6 & 1,0 & 1,5 & 1,4 & 1,3 & 1,9 & 2,3 & 1,0 & 1,5 \\
\hline Akmola & 1,8 & 0,9 & 1,5 & 1,8 & 1,0 & 1,1 & 2,0 & 1,0 & 1,4 \\
\hline Kostanay & 1,6 & 1,1 & 1,6 & 0,3 & 1,5 & 2,4 & 2,5 & 1,0 & 1,5 \\
\hline Pavlodar & 1,6 & 1,0 & 0,7 & 0,8 & 1,4 & 1,0 & 1,0 & 1,0 & 1,1 \\
\hline North Kazakhstan & 1,4 & 1,1 & 2,3 & 3,1 & 1,3 & 3,0 & 2,8 & 1,0 & 2,0 \\
\hline Western & 1,4 & 0,4 & 0,5 & 0,1 & 0,6 & 0,5 & 0,3 & 0,8 & 0,6 \\
\hline Aktobe & 2,4 & 0,3 & 0,7 & 0,1 & 0,5 & 0,3 & 0,5 & 0,7 & 0,7 \\
\hline Atyrau & 0,6 & 0,3 & 0,2 & 0,1 & 0,8 & 0,1 & 0,3 & 0,8 & 0,4 \\
\hline West Kazakhstan & 1,4 & 0,8 & 0,7 & 0,1 & 1,1 & 1,1 & 0,5 & 0,8 & 0,8 \\
\hline Mangistau & 1,2 & 0,1 & 0,3 & 0,1 & 0,1 & 0,1 & 0,3 & 0,8 & 0,4 \\
\hline Eastern & 1,4 & 0,7 & 1,2 & 0,6 & 1,1 & 0,9 & 0,8 & 1,0 & 1,0 \\
\hline East Kazakhstan & 1,4 & 0,7 & 1,2 & 0,6 & 1,1 & 0,9 & 0,8 & 1,0 & 1,0 \\
\hline Central & 3,7 & 0,2 & 0,6 & 0,1 & 0,6 & 0,4 & 0,5 & 1,1 & 0,9 \\
\hline Karaganda & 3,7 & 0,2 & 0,6 & 0,1 & 0,6 & 0,4 & 0,5 & 1,1 & 0,9 \\
\hline South & 0,4 & 2,3 & 0,6 & 2,3 & 1,3 & 0,7 & 0,8 & 1,1 & 1,2 \\
\hline Almaty & 0,4 & 2,2 & 0,8 & 1,3 & 0,9 & 0,8 & 0,5 & 1,1 & 1,0 \\
\hline Zhambyl & 0,5 & 2,2 & 0,4 & 2,3 & 0,9 & 0,6 & 0,8 & 1,1 & 1,1 \\
\hline Kyzylorda & 0,4 & 1,2 & 0,5 & 3,6 & 0,6 & 0,2 & 1,3 & 1,0 & 1,1 \\
\hline South Kazakhstan & 0,2 & 3,3 & 0,6 & 3,6 & 2,9 & 0,7 & 1,0 & 1,1 & 1,7 \\
\hline Total $R K$ & 1,0 & 1,0 & 1,0 & 1,0 & 1,0 & 1,0 & 1,0 & 1,0 & 1,0 \\
\hline
\end{tabular}


From the table 4 data it can be noted, that the land resources supply is the highest in the central region, the least in the southern region. Labor supply, on the contrary, is high in the southern region and low in the central and other regions. By indicator of the regions soil bonitet score is arranged in follow sequence: northern, eastern, southern, central, western. Most mineral fertilizers are introduced in the southern region, least in the western and eastern regions. The equipment supply is greatest in the northern region, the least in the western region. The share of rural settlements with roads to the district center with a paved is high in the southern region, low in the western region. The weighted average index of the total resource potential in the regions is changed as follows: the highest in the northern region, further decreases in the south, east central and western regions.

Then the average efficiency index manufacturing (APEIM) is determined by formula (1) and based on these indicators, the level of resource potential utilization efficiency (LRPUE) is determined by formula (3) (table 5):

Table 5. The average production efficiency index (APEIM) and the resource potential use efficiency level (LRPUE)

\begin{tabular}{|l|c|c|c|c|}
\hline \multicolumn{1}{|c|}{ Region } & APGO Index & PAP Index & APEIM & LRPUE Index \\
\hline Nothern & 1,025 & 1,412 & 1,219 & 0,8 \\
\hline Akmola & 0,852 & 1,352 & 1,102 & 0,8 \\
\hline Kostanay & 0,835 & 1,453 & 1,144 & 0,8 \\
\hline Pavlodar & 0,887 & 0,707 & 0,797 & 0,7 \\
\hline North Kazakhstan & 1,693 & 1,997 & 1,845 & 0,9 \\
\hline Western & 0,455 & 0,226 & 0,341 & 0,6 \\
\hline Aktobe & 0,498 & 0,202 & 0,350 & 0,5 \\
\hline Atyrau & 0,290 & 0,146 & 0,218 & 0,6 \\
\hline West Kazakhstan & 0,55 & 0,429 & 0,490 & 0,1 \\
\hline Mangistau & 0,08 & 0,03 & 0,055 & 0,9 \\
\hline Eastern & 1,077 & 0,818 & 0,948 & 0,9 \\
\hline East Kazakhstan & 1,077 & 0,818 & 0,948 & 0,4 \\
\hline Central & 0,438 & 0,275 & 0,357 & 1,6 \\
\hline Karaganda & 0,438 & 0,275 & 0,357 & 2,0 \\
\hline South & 1,979 & 1,827 & 1,903 & 1,2 \\
\hline Almaty & 1,882 & 2,060 & 1,971 & 0,7 \\
\hline Zhambyl & 1,452 & 1,232 & 1,342 & 1,7 \\
\hline Kyzylorda & 1,108 & 0,394 & 0,751 & 1,0 \\
\hline Turkestan & 3,214 & 1,000 & 1,967 & \\
\hline Total RK & 1,000 & & & \\
\hline *according to the Republic of Kazakhstan Statistics Committee data for $2015-2017$ & \\
Note - compiled by the authors &
\end{tabular}

As we see from the above data, the northern region is the most supplied with agricultural resources, but the cultivation of more intensive crops in the southern region supplies greater production efficiency and, therefore, a higher level's efficient use of agricultural resources.

\section{Discussion}

The resource potential use efficiency is formed of a series' interconnected components: the efficient use of the resource potential (staff, land, animals' and plants' biological potential) and the resource-saving technologies development. Resource potential in agricultural production should be formed with the need for production capacity. State support can increase as the agricultural enterprises resource potential, and so its implementation effectiveness (Ibrishev, 2019).

Currently, increasing the agricultural enterprises resource potential is a basis for creating conditions for their sustainable development. This basis' formation comes in two planes. One side, this is an increase in the level of economic entities resource supply and resource proportions optimization that ensure the creation of potentially efficient production enterprises systems. The other side, this is improving the organizational and economic relations system, which ensuring the objective acting economic laws implementation. Naturally, in the conditions of a weak state regulatory role and with a minimum state support level, the implementation measures which can be realized due to agricultural formations internal reserves are got high priority. The main problem with this is that the own growth potential reserves of the industry enterprises are almost exhausted. In conditions when the productive forces are degrading (besides the degradation rates are decreasing 
extremely slowly), improving the economic mechanism does not ensure an increase in production efficiency, since the contradictions between these economic systems components cannot be eliminated or reduced.

In general, the situation in the agricultural sector requires well-thought-out, long-term and systemic decisions based on objective data obtained as a result of the agricultural enterprises resource potential's integrated assessment.

\section{Conclusion}

1. An indicators system that form the efficiency agribusiness subjects, which based on its resource supply should be presented in three blocks: indicators of resource availability, their use efficiency's indicators and indicators of the resource use synergistic effect. Thus, it is almost impossible to conduct each element's isolated assessment of the resource potential.

2. Assessment's the agricultural production resource potential includes the consistent assessment: first, resources availability, then the agricultural production economic efficiency and, finally, the resource use efficiency in the agricultural production subjects.

3. The highest land use efficiency index was achieved in the southern region areas, where there are large arable lands, favorable climatic conditions (high thermal conditions, long growing season), and the presence of irrigated lands that allows to grow crops with high productivity. The lower efficiency is in the eastern region, the northern region areas are located in risky farming zone with an uneven rainfall amount over the years, so the fertile lands presence $-40-55$ bonitet scores, crop yields varies by year.

4. It was defined the resulting indicators complex, which reflecting the availability's level of agricultural production resources in the regions, including 10 indicators.

5. Comparative complex calculations showed that the northern region is the most supplied with agricultural resources, but the cultivation of more intensive crops in the southern region supplies greater production efficiency and, therefore, a higher level's efficient use of agricultural resources.

\section{References}

Alhazov, Sh.T. (2011). Metodicheskie podkhody k otsenke resursnoho potentsiala predpriiatii i otraslei rehiona [Methodological approaches to assessing the resource potential of enterprises and industries in the region]. Vestnik Volhohradskoho instituta biznesa - Bulletin of the Volgograd Institute of business, 1, 96-104 [in Russian].

Baráth, L., \& Fertő, I. (2017). Productivity and convergence in European agriculture. Journal of Agricultural Economics, 68(1), 228-248.

Bronshtein, M.L. (1972). Optimizatsiia ispolzovaniia zemli i sistema otsenok. Voprosy sovershenstvovaniia planovoho upravleniia i hozraschetnoho mechanizma optimizatsii ispolzovaniia zemelnykh resursov [Optimization of land use and assessment system. Issues of improving planned management and self-financing mechanism for optimizing the use of land resources]. Estonskoe otdelenie TcEMI - The Estonian branch of the CEMI, 4-14 [in Russian].

Davis, K.F., Gephart, J.A., Emery, K.A., Leach, A.M., Galloway, J.N., \& D’Odorico, P. (2016). Meeting future food demand with current agricultural resources. Global Environmental Change, 39, 125-132.

Davydkina O.A. (2015). Innovatsionnoe razvitie resursnoho potentsiala selskoho khoziaistva rehiona [Innovative development of the resource potential of agriculture in the region]: monohrapkhiia. Privolzhskii dom znanii - monograph: Privolzhsky house of knowledge, 116 [in Russian].

De Olde, E.M., Oudshoorn, F.W., Sørensen, C.A., Bokkers, E.A., \& De Boer, I.J. (2016). Assessing sustainability at farm-level: Lessons learned from a comparison of tools in practice. Ecological Indicators, 66, 391-404.

Gutzler, C., Helming, K., Balla, D., Dannowski, R., Deumlich, D., Glemnitz, M., ... \& Sieber, S. (2015). Agricultural land use changes-a scenario-based sustainability impact assessment for Brandenburg, Germany. Ecological indicators, 48, 505-517.

Ibrishev, N.N. (2019). Resursy kak osnova effektivnoho funktsionirovaniia ahropromyshlennoho kompleksa [Resources as a basis for the effective functioning of agricultural industry]. Kazahskii NII ekonomiki APK i razvitiia selskikh territorii - Kazakh research Institute of agriculture and rural development, 40-47 [in Russian].

Kalnynsha, A.A. (Ed.). (1998). Ekonomicheskii mechanism khoziaistvovaniia [Economic mechanism of management]. Ahropromizdat - Agro-industrial publishing house, 287 [in Russian].

Krastin, O., \& Godmane, I. (1984). Rehressionnoe modelirovanie pri reshenii ekonomicheskikh zadach [Regression modeling for solving economic problems]. Yekonomika selskoho khoziaistva - Agricultural economics, 1, 60 [in Russian].

Minviel, J.J., \& Latruffe, L. (2017). Effect of public subsidies on farm technical efficiency: a meta-analysis of empirical results. Applied Economics, 49(2), 213-226.

Mogaji, K.A., Lim, H.S., \& Abdullah, K. (2015). Regional prediction of groundwater potential mapping in a multifaceted geology terrain using GIS-based Dempster-Shafer model. Arabian Journal of Geosciences, 8(5), 3235-3258. 
Pershukevich, P.M. (2001). APK Sibiri: taktika i stratehiia ekonomicheskikh reform [Agro-industrial complex of Siberia: tactics and strategy of economic reforms]. RASH Sibirskoe otdelenie SibNIIESH - Russian Academy of agriculture Siberian branch, 321 [in Russian].

Romanova O.A., Bryanceva O.C., \& Pozdnyakova E.A. (2013). Resursnyi potentsial reindustrializatsii staropromyshlennoho rehiona [Resource potential of reindustrialization of the old industrial region]. Yekaterinburg: Institut ekonomiki UrO RAN — Institute of Economics Ural branch of the Russian Academy of Sciences, 251 [in Russian].

Walters, J.P., Archer, D.W., Sassenrath, G.F., Hendrickson, J.R., Hanson, J.D., Halloran, J.M., ... \& Alarcon, V.J. (2016). Exploring agricultural production systems and their fundamental components with system dynamics modelling. Ecological modelling, 333, 51-65.

Yang, L., \& Zhang, X. (2018). Assessing regional eco-efficiency from the perspective of resource, environmental and economic performance in China: A bootstrapping approach in global data envelopment analysis. Journal of Cleaner Production, 173, 100-111.

Yuzefovich, A.E. (1987). Ahrarnyi resursnyi potentsial: formirovanie $i$ ispolzovanie [Agricultural resource potential: formation and use]. Kiev: Naukova Dumka [in Russian].

\section{Б. Наукенова, А. Пягай \\ Ресурстық әлеуетті пайдаланудын экономикалық тиімділігі негізінде ауыл шаруашылығы өндірісін тұрақты дамыту}

\section{Ацдатпа}

Maқcambl: ҚР аграрлық секторының ресурстық әлеуетін (табиғи, еңбек, материалдық-техникалық және т.б.) бағалау және оның дамуының тежеуші факторларын анықтау.

Әдістері: 1. Сомасы шаруашылықтардың ресурстарымен қамтамасыз етілу көрсеткіші ретінде ұсынылатын жер және материалдық ресурстарды экономикалық бағалау.

2. Өндірістік ресурстар мен өндіріс нәтижелері арасындағы байланысты көрсететін экономикалықстатистикалық. әдістері.

3. Ресурстық әлеуетті оның құрамдас элементтерінің ерекшеліктерін ескере отырып, бағалаудың индекстік

Қорытынды: 1. Ауыл шаруашылығы мақсатындағы жерлердің өнімділік қабілетін бағалау шаруашылықтың барлық санаттарындағы өндірілетін ауыл шаруашылығы өнімінің жылдық көлемінің көрсеткіші арқылы оның кадастрлық құнына сәйкес 1 га, сондай-ақ индекс әдісін қолдана отырып, 1 га егістікке өндірілетін өсімдік шаруашылығы өнімінің көлемі арқылы жүзеге асыру.

2. Ауыл шаруашылығы өндірісінің ресурстық әлеуетін бағалау алдымен ресурстармен қамтамасыз етілуін, содан кейін ауыл шаруашылығы өндірісінің экономикалық тиімділігін дәйекті бағалауды және ауыл шаруашылығы өндірісі субъектілерінде ресурстарды пайдалану тиімділігін қорытындылауды қамтиды.

Тұжырымдама: 10 көрсеткішті қамтитын өңірлердің ауыл шаруашылығы өндірісін ресурстармен қамтамасыз ету деңгейін көрсететін нәтиже көрсеткіштерінің кешені анықталды.

Kiлm сөздер: ауыл шаруашылығы өндірісі, ресурстық әлеует, аграрлық сектор, экономикалық тиімділік, ресурстарды пайдалану тиімділігі, интегралдық бағалау, агроөнеркәсіптік кешен.

\section{Б. Наукенова, А. Пягай}

\section{Устойчивое развитие сельскохозяйственного производства на основе экономической эффективности использования ресурсного потенциала}

Аннотация

Цель: оценка ресурсного потенциала (природного, трудового, материально-технического и др.) развития аграрного сектора РК и определение сдерживающих факторов его развития.

Memodbl: 1. Экономическая оценка земельных и материальных ресурсов, сумма которых представляется в качестве показателя ресурсообеспеченности хозяйств.

2. Экономико-статистические, отражающие связь между производственными ресурсами и результатами производства.

3. Индексные методы оценки ресурсного потенциала с учетом особенностей его составляющих элементов.

Pезультаты: 1. Оценка производительной способности земель сельскохозяйственного назначения осуществлен через показатель годового объема производимой продукции сельского хозяйства во всех категориях хозяйств в соответствии с ее кадастровой стоимостью в расчете на 1 га, а также производимой продукции растениеводства на 1 га пашни с применением индексного метода.

2. Оценка ресурсного потенциала сельскохозяйственного производства включает в себя последовательную оценку вначале обеспеченности ресурсами, затем экономической эффективности сельскохозяйственного произ- 
водства и, в заключение, эффективности использования ресурсов в субъектах сельскохозяйственного производства.

Bblвoдbl: Определен комплекс из 10 результирующих показателей, отражающих уровень обеспеченности сельскохозяйственного производства регионов ресурсами.

Ключевые слова: сельскохозяйственное производство, ресурсный потенциал, аграрный сектор, экономическая эффективность, эффективность использования ресурсов, интегральная оценка, агропромышленный комплекс.

\section{References}

Алхазов Ш.Т. Методические подходы к оценке ресурсного потенциала предприятий и отраслей региона / Ш.Т. Алхазов // Вестн. Волгоград. ин-та бизнеса. — 2011. — № 1. - С. 96-104.

Baráth L. Productivity and convergence in European agriculture / L. Baráth, I. Fertő // Journal of Agricultural Economics. - 2017. - T. 68. - № . 1. - C. 228-248.

Бронштейн М.Л. Оптимизация использования земли и система оценок. Вопросы совершенствования планового управления и хозрасчетного механизма оптимизации использования земельных ресурсов / М.Л. Бронштейн. — Тарту: Эстон. отд. ЦЭМИ, 1972. - С. 4-14.

Davis K.F. Meeting future food demand with current agricultural resources / K.F. Davis et al. // Global Environmental Change. - 2016. - T. 39. - C. 125-132.

Давыдкина О.А. Инновационное развитие ресурсного потенциала сельского хозяйства региона: моногр. / О.А. Давыдкина - Пенза: Приволж. дом знаний, 2015. - 116 с.

De Olde E.M. Assessing sustainability at farm-level: Lessons learned from a comparison of tools in practice / E.M. De Olde et al. // Ecological Indicators. - 2016. — T. 66. - C. 391-404.

Gutzler C. et al. Agricultural land use changes-a scenario-based sustainability impact assessment for Brandenburg, Germany / C. Gutzler et al. // Ecological indicators. - 2015. - T. 48. - C. 505-517.

Ибришев Н.Н. Ресурсы как основа эффективного функционирования агропромышленного комплекса / Н.Н. Ибришев. - Алматы: Казах. НИИ экономики АПК и развития сельских территорий, 2019 - С. 40-47.

Экономический механизм хозяйствования / под ред. А.А. Калныньша. - М.: Агропромиздат, 1998. - 287 с.

Крастинь О. Регрессионное моделирование при решении экономических задач / О. Крастинь, И. Годмане // Экономика сельского хозяйства. - 1984. - № 1. - С. 60.

Minviel J.J. Effect of public subsidies on farm technical efficiency: a meta-analysis of empirical results / J.J. Minviel, L. Latruffe // Applied Economics. - 2017. - T. 49. - № . 2. - C. 213-226.

Mogaji K.A. Regional prediction of groundwater potential mapping in a multifaceted geology terrain using GIS-based Dempster-Shafer model / K.A. Mogaji, H.S. Lim, K. Abdullah // Arabian Journal of Geosciences. — 2015. — T. 8. — № . 5. - С. 3235-3258.

Першукевич П.М. АПК Сибири: тактика и стратегия экономических реформ / П.М. Першукевич; РАСХ Сиб. отд-ние СибНИИЭСХ. - Новосибирск, 2001. - 321 с.

Романова О.А. Ресурсный потенциал реиндустриализации старопромышленного региона / О.А. Романова, О.С. Брянцева, Е.А. Позднякова. - Екатеринбург: Ин-т экономики УрО РАН, 2013. — 251 с.

Walters J.P. Exploring agricultural production systems and their fundamental components with system dynamics modelling / J.P. Walters et al. // Ecological modelling. — 2016. - T. 333. - C. 51-65.

Yang L. Assessing regional eco-efficiency from the perspective of resource, environmental and economic performance in China: A bootstrapping approach in global data envelopment analysis / L. Yang, X. Zhang // Journal of Cleaner Production. - 2018. - T. 173. - C. 100-111.

Юзефович А.Э. Аграрный ресурсный потенциал: формирование и использование / А.Э. Юзефович. - Киев: Наук. думка, 1987. - 352 с. 